\title{
Hydrocarbons in the Suspended Matter and the Bottom Sediments in Different Regions of the Black Sea Russian Sector
}

\author{
I. A. Nemirovskaya*, V. D. Onegina, B. V. Konovalov \\ P.P. Shirshov Institute of Oceanology, Russian Academy of Sciences, Moscow, Russian Federation \\ *e-mail: nemir@ocean.ru
}

Content and composition of hydrocarbons (mainly the aliphatic ones) in the suspended matter and the bottom sediments in the Gelendzhik Bay, the Big Sochi water area, the Feodosiya Bay and the Black Sea central part are defined and compared with the total organic carbon and chlorophyll $a$ contents. It is shown that the aliphatic hydrocarbon concentrations exceeding the background ones are found only in the coastal zone. Advancing to the pelagic zone is accompanied by sharp decrease of their concentrations.

Petroleum and pyrogenic hydrocarbons are mainly manifested in the polycyclic aromatic hydrocarbons composition. Influence of construction of the Olympic facilities upon distribution of hydrocarbons in the Big Sochi water area was of short duration, and already by 2015 the aliphatic hydrocarbons concentration decreased, on the average, up to $24 \mu \mathrm{g} / \mathrm{l}$ in the surface waters, and up to $18 \mu \mathrm{g} / \mathrm{g}$ - in the bottom sediments.

Accumulation of hydrocarbons took place in bottom sediments, where their concentrations exceeded the background ones in terms of dry weight. In the Gelendzhik Bay, their content reached $252 \mu \mathrm{g} / \mathrm{g}$, and in the composition of organic carbon $\left(C_{o r g}\right)>1 \%$, which may indicate the contamination of sediments with oil products. In the Feodosiya Bay their part in the composition of $C_{\text {org }}$ did not exceed $0.73 \%$ and was $0.35 \%$ on average.

Natural alkanes dominated in the composition of aliphatic hydrocarbons. The bottom sediments are characterized by the predominance of odd high-molecular terrigenous alkanes.

The content of polycyclic aromatic hydrocarbons in the studied sediments was rather low: up to $31 \mathrm{ng} / \mathrm{g}$ in the Gelendzhik Bay, up to $348 \mathrm{ng} / \mathrm{g}$ in the Feodosiya Bay. These concentrations according to the EPA classification are considered background, or minor petroleum hydrocarbons increase the level of aliphatic hydrocarbons in water and sediments, thus creating a modern hydrocarbon background.

Keywords: aliphatic hydrocarbons, polycyclic aromatic hydrocarbons, alkanes, suspended matter, bottom sediments, oil pollution.

DOI: 10.22449/1573-160X-2017-4-46-58

(C) 2017, I. A. Nemirovskaya, V. D. Onegina, B. V. Konovalov

(C) 2017, Physical Oceanography

Introduction. The Black Sea is the area of intensive navigation. The annual volume of oil transportation here in the near future may grow up to 220-250 million tons [1]. What is more, about 50,000 merchant ships and 150 warships cruise annually in the sea. All this creates a potential threat of oil spills. Taking into account the specific accidental loss (30 tons per 1 million tons of the oil products transported [2]), the total volume of accidental spills in the area can be about 7500 tons per year [1]. At the same time, there has been an increase in the volume of illegal oil and oil products (hereinafter, oil products) transshipment in the sea on the way to the Black Sea part of the Kerch Strait. Hazard areas in the Black Sea Russian sector include the areas adjacent to the cities of Novorossiysk, Gelendzhik, Tuapse, Sochi and Sevastopol, including berths where technological waters and domestic waste are discharged into the sea [2-4]. 
Hydrocarbons (HC) are the bulk of oil products (up to $95 \%$ ) [5, 6]. Therefore, due to the complexity of the analysis, the modern system of environmental monitoring is based on the determination of HC content, which is often called oil, without taking into account the natural marine hydrocarbon background [7]. In order to find out the current level of pollution by oil products in various areas of the Black Sea Russian sector, the research of aliphatic hydrocarbons (AHC), including alkanes and polycyclic aromatic hydrocarbons (PAHC), in the suspended matter and the bottom sediments was carried out in the present work.

The main difficulty in the sea oil pollution data interpretaion, especially at low (background) levels, is associated with the existence of natural sources (apart from anthropogenic ones) of hydrocarbons entering the marine environment. These include the processes of life and metabolism of marine organisms, accompanied by $\mathrm{HC}$ biosynthesis, and are permanent components of organic matter (OM) [6, 8]. Beyond that, a significant contribution to the overall hydrocarbon balance is made by natural oil inflows from the sedimentation mass, which includes mud volcanism, natural gas and oil fluids and gas hydrates [2, 3]. Consequently, the relevance of defining the $\mathrm{HC}$ content and composition for a real assessment of oil pollution in the water areas is beyond doubt.

Materials and methods. During the research in the 2012-2015 period 123 samples of the suspended matter isolated from surface waters, 14 samples taken from different horizons and 53 samples of bottom sediments were selected and analyzed. Water samples were collected from surface during the vessel approach to the station to avoid film penetration. To take samples from the depth horizons a plastic bathometer was applied. To define organic compounds, including HCs, the suspended matter was isolated on pre-calcinated GF/F $(0.7 \mu \mathrm{m})$ glass fiber filters at $450{ }^{\circ} \mathrm{C}$. To define the suspended matter concentration and composition - on the preliminarily washed (by $4 \%$ pure saline acid) and suspended polycarbonate nuclear filters $(0.45 \mu \mathrm{m})$ under vacuum at $0.4 \mathrm{~atm}$. Samples of bottom sediments were taken by an Ocean bottom sampler.

Hydrocarbons were extracted from samples of the suspended matters and bottom sediment samples dried at $50^{\circ} \mathrm{C}$ on a Sapphir ultrasonic bath. A fraction of 0.25-0.5 mm was previously isolated from bottom sediments for sieve analysis. The extractant was methylene chloride. Lipids (total extractable fraction) were defined before column chromatography on silica gel, AHC - after column chromatography on silica gel; AHC were isolated with hexane, PAHC - with a mixture of hexane and benzene (3:2) [6]. The concentration of lipids and AHC was defined by the IR method using the $2930 \mathrm{~cm}^{-1}$ band. A mixture of $37.5 \%$ isooctane, $37.5 \%$ hexadecane and $25 \%$ benzene [5] was used as a standard on the IR Affinity1 Shimadzu instrument (Japan).

The composition of alkanes was defined by the method of capillary gas-liquid chromatography (column $30 \mathrm{~m}$ long, ZB-5 liquid phase) on an Intersmat GC 121-2 chromatograph equipped with a flame ionization detector when programming temperature from 100 to $320^{\circ} \mathrm{C}$ at a velocity of $8 \%$ min.

The PAHC content and composition was found by high performance liquid chromatography on an LC-20 Prominence Shimadzu chromatograph with an Envirosep $P P$ column and a $R F-20 A$ fluorescent detector. The instrument was calibrated 
applying individual PAHCs and their mixtures produced by Supelco. As dominant ones the following PAHCs were defined: naphthalene $(\mathrm{N})$, phenanthrene $(\mathrm{Ph})$, anthracene (AN), fluoranthene (FL), pyrene (P), chrysene (CHR), perylene (PL), benz (a) pyrene (BP), 1.12-benzperylene (BPL).

Organic carbon $\left(\mathrm{C}_{\text {org }}\right)$ in the bottom sediments was defined by the method of dry burning on the domestic $A N-7529$ analyzer. A factor of 0.86 was used to recalculate the AHC concentrations in the sediments in the $\mathrm{C}_{\text {org }}$ concentration [6].

Determination of chlorophyll $a$ concentration was carried out by spectrophotometric method according to [9].

Results and discussion. In the Gelendzhik Bay in the summer of 2012 the AHC concentrations in surface waters varied within the range of 5-15 $\mu \mathrm{g} / 1$, the mean value was $9 \mu \mathrm{g} / \mathrm{l}$ (Tab. 1). It was even lower than the background level for coastal marine areas $(20 \mu \mathrm{g} / 1$ [6]) and much lower than the TLV for the petroleum HCs $(50 \mu \mathrm{g} / 1)$. Elevated AHC, as well as chlorophyll $a$ concentrations, were observed in the coastal area, especially in its eastern part. The same distribution of AHC in surface waters was monitored in this area in 2010 [7] and, most likely, it was due to the water dynamics. Mathematical modeling has shown [10] that the main water flow enters the bay from the open sea through the center of the neck. It can promote the polluted dilution water in the bay. Further, the water flow reaches the shore and forms whirlpools in the western part of the bay and a stronger one in its eastern part. The western part of the bay is better ventilated than the eastern one. There the outflowing water can be involved in the circulation several times. Therefore, the AHC, chlorophyll $a$ and suspended matter concentrating takes place in the east of the bay. Fragments of mineral particles, diatoms, as well as combustion spheres were the basis of the suspended matter at coastal stations [10]. In the summer 2013 the AHC content in surface waters increased (up to 18-20 $\mu \mathrm{g} / \mathrm{l}$ on average), but remained below the TLV values. The area of increased concentrations in the Gelendzhik Bay moved to the north-west, but remained in the coastal zone (Fig. 1, a).
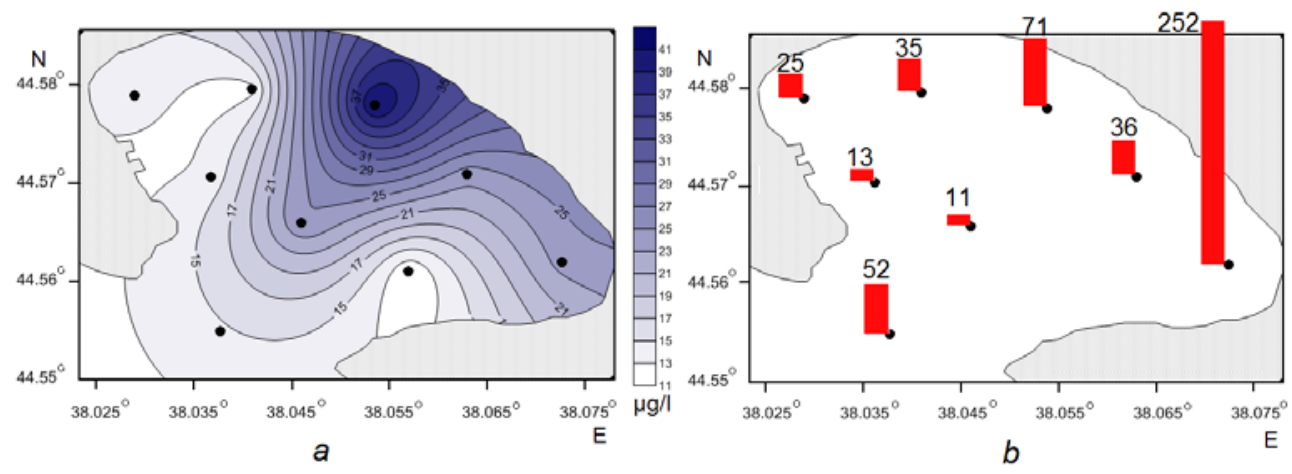

Fig. 1. The AHC distribution in the Gelendzhik Bay in summer 2013: $a$ - in surface waters ( $\mu \mathrm{g} / \mathrm{l}) ; b-$ in the surface layer of the bottom sediments $((\mu \mathrm{g} / \mathrm{g})$.). The sampling stations are marked by dots 
Biogenic low-molecular autochthonous alkanes prevailed in the composition of AHCs isolated from suspended surface waters; the ratio of low- to high-molecular homologues varied within the range of 4-5. The main source of AHC was phytoplankton, as indicated by a maximum at $n-C_{17}$, and an increase in $n-C_{20}$ homologs, $-\mathrm{C}_{22}$ indicated their microbial transformation [6]. The smooth distribution of homologues in the high molecular weight region (CPI $=0.95-1.07)$ is typical for the suspended matter alkanes and can be due to the presence of both natural and weathered oil hydrocarbons. A similar composition of alkanes is characteristic for the water column of the Black and Azov Seas [11].

In June 2015, on the Gelendzhik Bay section - the open sea the AHC concentrations in surface waters were practically constant $(24 \mu \mathrm{g} / \mathrm{L}$ on average, Tab. 1). The existence of a correlation between the content of AHC and lipids $(r=0.94, n=$ $=18$ ) both in the surface layer and in the entire water column indicates a high degree of AHC transformation [6].

Table 1

Content of Organic Compounds in the Suspended Surface Water

\begin{tabular}{|c|c|c|c|c|c|c|c|c|}
\hline \multirow{2}{*}{ Area } & \multicolumn{2}{|c|}{ AHC, $\mu \mathrm{g} / \mathrm{l}$} & \multicolumn{2}{|c|}{ Lipids, $\mu \mathrm{g} / \mathrm{l}$} & \multicolumn{2}{|c|}{ Ch $a, \mu \mathrm{g} / \mathrm{l}$} & \multicolumn{2}{|c|}{ Susp.matter, $\mu \mathrm{g} / \mathrm{l}$} \\
\hline & Interval & Average & Interval & Average & Interval & Average & Interval & Average \\
\hline \multicolumn{9}{|c|}{2012} \\
\hline $\begin{array}{l}\text { Gelendzhik } \\
\text { Bay }\end{array}$ & $5-15$ & 9 & $22-40$ & 31 & $0.25-1.90$ & 0.60 & $0.58-1.62$ & 0.90 \\
\hline \multicolumn{9}{|c|}{2013} \\
\hline $\begin{array}{l}\text { Gelendzhik } \\
\text { Bay }\end{array}$ & $11-42$ & 20 & $33-100$ & 58 & $0.15-1.30$ & 0,30 & \multicolumn{2}{|c|}{ No data } \\
\hline Big Sochi & 4-675 & 47 & $58-876$ & 120 & $0.14-0.37$ & 0.27 & $1.38-31.57$ & 6.88 \\
\hline \multicolumn{9}{|c|}{2014} \\
\hline $\begin{array}{l}\text { Gelendzhik } \\
\text { Bay * }\end{array}$ & $2-67$ & 15 & \multicolumn{6}{|c|}{ No data } \\
\hline Big Sochi & $4-84$ & 22 & $7-357$ & 74 & $0.36-1.73$ & 0.89 & $1.16-8.70$ & 3.46 \\
\hline \multicolumn{9}{|c|}{2015} \\
\hline $\begin{array}{l}\text { Gelendzhik } \\
\text { Bay - open } \\
\text { sea }\end{array}$ & $23-24$ & 24 & $76-123$ & 94 & $0.20-0.51$ & 0.34 & $0.28-0.41$ & 0.35 \\
\hline Big Sochi & $14-33$ & 24 & $28-119$ & 63 & \multicolumn{2}{|c|}{ No data } & $1.45-31.10$ & 12.25 \\
\hline $\begin{array}{l}\text { Feodosiya } \\
\text { Bay }\end{array}$ & $14-90$ & 35 & $32-213$ & 83 & $0.03-0.28$ & 0.12 & $0.44-2.38$ & 1.2 \\
\hline $\begin{array}{l}\text { Black Sea } \\
\text { central part }\end{array}$ & $9-21$ & 14 & $24-47$ & 37 & $0.01-0.22$ & 0.14 & $0.24-0.38$ & 0.28 \\
\hline
\end{tabular}

*According to the data of [23].

The bottom sediments selected in the summer 2013 in the Gelendzhik Bay were mainly represented by silty sandy material with a moisture content of 21 $34 \%$ (28\% on average) and AHC content of 11-252 $\mu \mathrm{g} / \mathrm{g}$ (Tab. 2). Both AHC and OB concentrations, as a whole, depend on the granulometric composition of sediments. The highest values are observed in the bottom sediments with an increased content of silt fraction (Fig. 1, $b$ ). The established values exceeded the background concentrations (10 $\mu \mathrm{g} / \mathrm{g}$ for sandy sediments, $50 \mu \mathrm{g} / \mathrm{g}$ for silty sediments $[6,12])$. 
At many stations the AHC content in the composition of $\mathrm{C}_{\text {org }}$ was more than $1 \%$ (Tab. 2), which is typical for the sediments contaminated with oil [6].

Table 2

Content of Organic Compounds in the Surface Layer of the Bottom Sediments

\begin{tabular}{|c|c|c|c|c|c|c|c|c|}
\hline \multirow{2}{*}{$\begin{array}{c}\text { Amount } \\
\text { of sam- } \\
\text { ples }\end{array}$} & \multirow{2}{*}{ Area } & \multicolumn{2}{|c|}{$\mathrm{AHC}, \mu \mathrm{g} / \mathrm{g}$} & \multicolumn{2}{|c|}{$\mathrm{C}_{\text {org, }} \%$} & \multirow{2}{*}{$\begin{array}{c}\text { AHC, } \% \\
\text { Corg }^{2}\end{array}$} & \multicolumn{2}{|c|}{ Humidity, \% } \\
\hline & & Interval & Average & Interval & Average & & Interval & Average \\
\hline \multicolumn{9}{|c|}{2013} \\
\hline 8 & $\begin{array}{l}\text { Gelendzhik } \\
\text { Bay }\end{array}$ & $11-252$ & 62 & 0.09-0.69 & 0.32 & 1.62 & $21-34$ & 28 \\
\hline \multicolumn{9}{|c|}{2014} \\
\hline 18 & Big Sochi & 5-119 & 31 & $0.06-0.35$ & 0.14 & 2.1 & $22-26$ & 24 \\
\hline \multicolumn{9}{|c|}{2015} \\
\hline 8 & $\begin{array}{l}\text { Gelendzhik } \\
\text { Bay - open sea }\end{array}$ & $4-28$ & 15 & $0.57-1.31$ & 1.03 & 0.13 & $34-57$ & 45 \\
\hline 2 & Big Sochi & $14-21$ & 18 & $0.25-0.58$ & 0.41 & 0.48 & $22-33$ & 27 \\
\hline 9 & Feodosiya Bay & $17-80$ & 33 & $0.39-1.16$ & 0.88 & 0.35 & $24-54$ & 45 \\
\hline 6 & $\begin{array}{l}\text { Black Sea central } \\
\text { part }\end{array}$ & $23-34$ & 27 & $1.54-4.70$ & 3.26 & 0.09 & $55-94$ & 72 \\
\hline
\end{tabular}

However, biogenic natural AHC dominate in the alkanes: in the low-molecular area both, as in surface waters, $-\mathrm{n}-\mathrm{C}_{17}$ homologue; in the high-molecular area - the increased content in a series of odd $n-\mathrm{C}_{27}-\mathrm{C}_{31}$ homologues of the terrigenous nature $[6,12]$. In the transformation of petroleum HCs, alkanes (especially low molecular ones) are the first to disappear, however, the intensive autochthonous processes occurring at the water - sediment boundary contribute to the formation of biogenic compounds $\left(n-C_{17}\right)$. Such a composition of alkanes is established in the sediments of coastal areas not only of the Black Sea [11, 13], but also of other seas [6].

Content of dominant PAHCs ( 57 PAHC) in the sediments of this area varied within the range of 23-31 ng/g. Their number (in \%) decreased in the following sequence: $\mathrm{Ph}$ (24.6) > FL (24.0) > XP (21.0) > PL (14.5) > BP (5.7) > Ph (5.6) > $>$ BPL (4.6). Despite the relatively small area of the Gelendzhik Bay, the PAHC content varied depending on the location of the stations (Fig. 2, a). Pyrene (the marker of pyrogenic processes) prevailed over perylene, which has a natural terrigenous origin [12, 14 and 15], and at coastal stations 116 and 118 the P/PL ratio was 2.7-3.8. This may indicate the penrtration of fresh products of oil combustion. Also, at coastal stations, the fluoranthene concentration was higher than that of phenanthrene of natural origin ( $\mathrm{FL} / \mathrm{F}=5.6-10.0)$, unlike the station 112 , located in the central part of the bay, where this ratio was only 1.5. It all goes to show that the source of pollution is the coastal zone.

In June 2015 in alevripelitic sediments in the Gelendzhik Bay - the Black Sea open part section, the AHC content was low both in terms of dry weight $(4-28 \mu \mathrm{g} / \mathrm{g})$ and in $\mathrm{C}_{\mathrm{org}}(0.13 \%, \mathrm{Tab} .2)$, i. e, just as in waters, corresponded to the background level. 


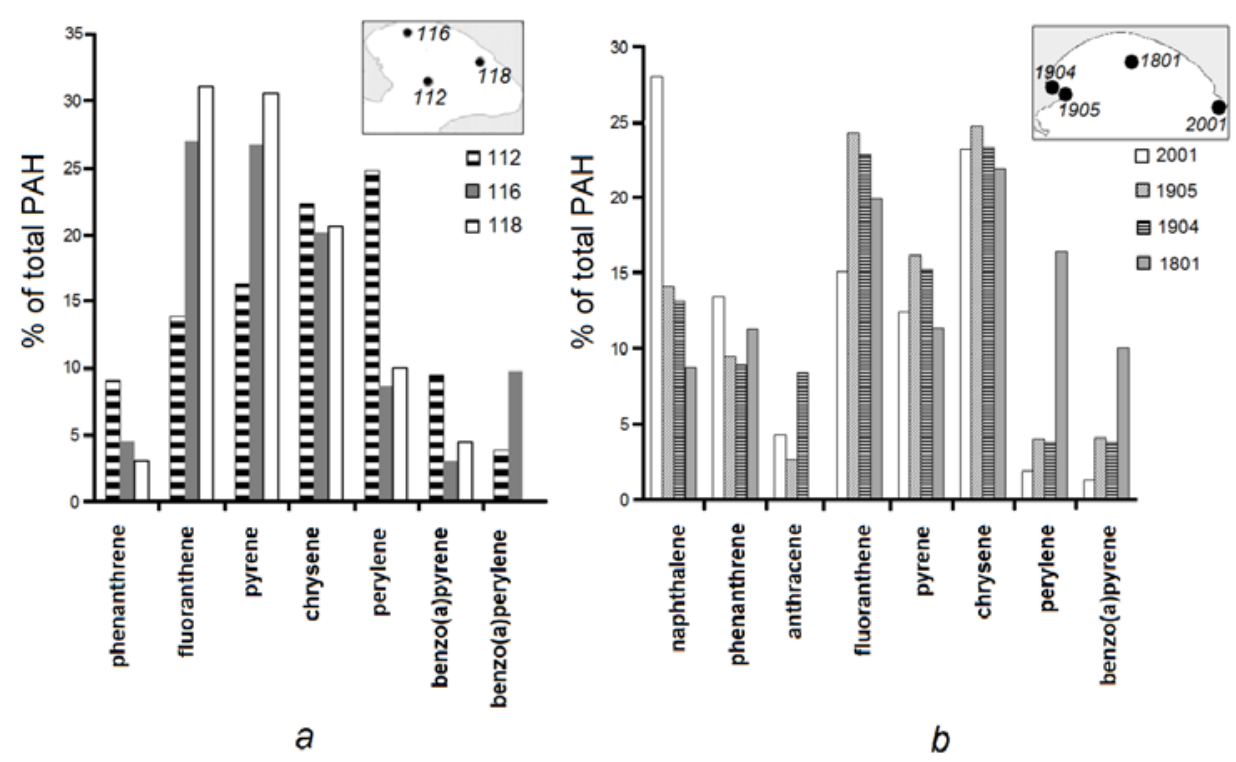

Fig. 2. Ratio of unsubstituted PAHC in the bottom sediments: $a$ - in the Gelendzhik Bay; $b$ - in the Feodosiya Bay (the sections above show the location of the stations)

In the Big Sochi coastal area the highest concentrations of AHC in surface waters were established in May 2013 and were 4-675 $\mu \mathrm{g} / 1$ (Tab. 1). In the area of the Mzymta River inflow the maximum concentration was $238 \mu \mathrm{g} / 1,78 \mu \mathrm{g} / \mathrm{l}$ on average, 1.6 TLV. According to the model proposed by academician Alexander Lisitsyn [16], the area of river and sea water mixing (marginal filter) consists of three main zones that differ in principle according to their functions: gravitational, physical-chemical and biological. In the gravitational zone due to the backwater of river waters by the sea one, sedimentation of sandy-silty fractions occurs. This area is characterized by high water turbidity and complicated photosynthesis. In the physical-chemical area colloids and dissolved compounds are captured (flocculation and coagulation zone). After sedimentation of various compounds with the clarification of water phytoplankton is developing and a biological zone arises (assimilation and transformation of dissolved substances of mineral and organic composition). On the geochemical barrier of the Mzymta - the Black Sea, the AHC content in surface waters decreased by a factor of 6 when passing from river to sea waters. The AHC distribution was governed by the marginal filter regularities and correlated with the suspended matter content $(r=0.95, n=13)$. In the gravitational zone with the sedimentation of large particles of suspended matter, the sharpest decrease in the AHC content took place (Fig. 3). "Losses" in their concentrations reached $74 \%$. In the physical-chemical zone $(S=1.5 \mathrm{eps})$ in the flocculation and coagulation processes, the AHC content reached $80 \mu \mathrm{g} / \mathrm{l}$. In the biological zone ( $S=13.5$ eps) with water clarification and phytoplankton formation, the AHC concentration also increased, but to a lesser extent than in other zones of the marginal filter (up to $60 \mu \mathrm{g} / \mathrm{l}$ ). 


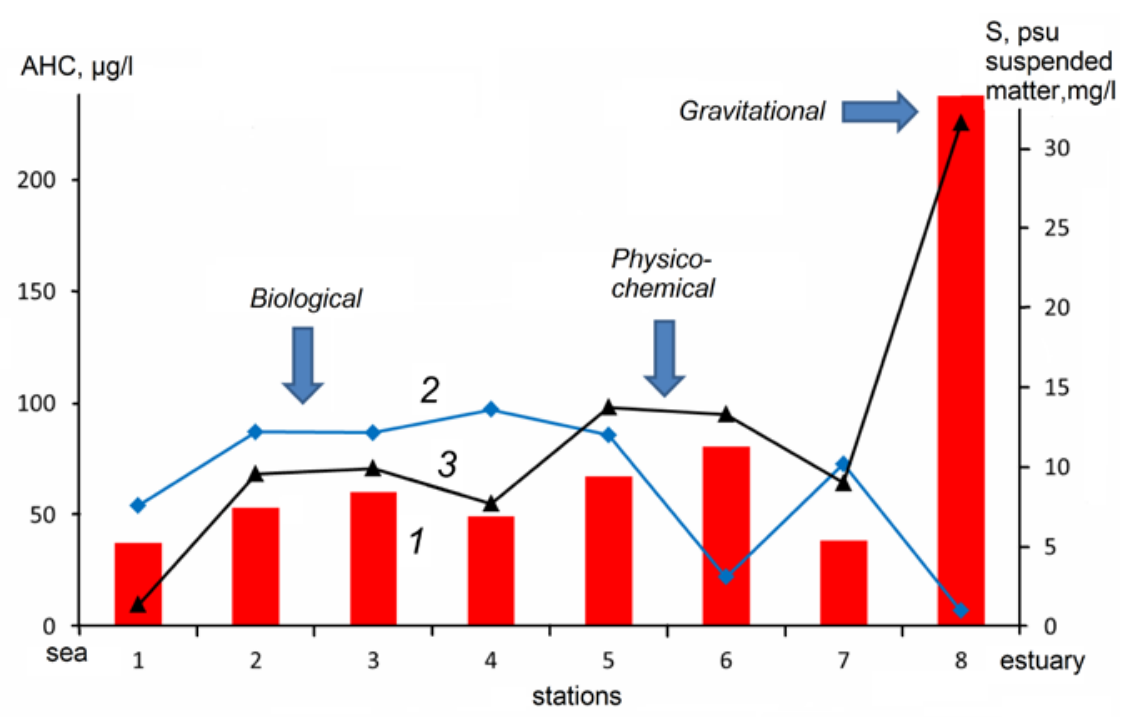

Fig. 3. Distribution of the AHC concentrations in surface waters (1), salinity (2) and suspended matter (3) on the geochemical barrier of the Mzymta - the Black Sea (May 2013)

In the area of the Kudepsta River inflow the AHC content was lower than in the Mzymta estuary area, but also decreased by a factor of 2 in the transition from the river waters to the sea ones. Apparently, the latter is due to the Kudepsta water catch peculiarity, its smaller runoff compared with the Mzymta, as well as to the isolated location from the construction of Olympic facilities. The highest concentrations of AHC in this area are found in the Bikhta River waters (32-675 $\mu \mathrm{g} / \mathrm{L}, 127 \mu \mathrm{g} / \mathrm{L}$ on average, $n=7$ ), flowing through the waste landfill, which caused its severe pollution by organic (15 times higher than the background) and biogenic substances (by silicates - 18 times, by ammonia nitrogen -40 times higher than the background) [17]. When the river waters were diluted by the sea ones, the AHC content gradually decreased. However, in the seaward stations of the section, the AHC level remained quite high - 38-53 $\mu \mathrm{g} / \mathrm{l}$.

In May 2014, after the Olympic construction termination, the AHC content in the surface waters of this area decreased by 1.6 times on average (up to $32 \mu \mathrm{g} / \mathrm{l}$ ), the suspended matter content - by 2 times nearly $(3.46 \mu \mathrm{g} / \mathrm{l})$.

In May 2015, there was a further decrease in the AHC concentrations against the background of an increase in the suspended matter content (Tab. 1). At the same time, a sharp decrease (in 6 times) of the AHC content at the Bikhta inflow area is worth to be noted (Fig. 4), which is associated with the waste landfill closure.

By 2015 there was also a decrease in the AHC concentrations from of 31 to $18 \mu \mathrm{g} / \mathrm{g}$ (Tab. 2) on average in the sandy coastal bottom sediments in the Big Sochi area. The low content in $\mathrm{C}_{\text {org }}$ composition $(<1 \%)$ indirectly indicates the natural origin of AHC.

In May 2015 in the the Feodosiya Bay surface waters the AHC content varied within the range of 14-90 $\mu \mathrm{g} / 1$ (Tab. 1) and decreased from Chauda Cape to Feodosiya port (Fig. 5, $a$ ). 


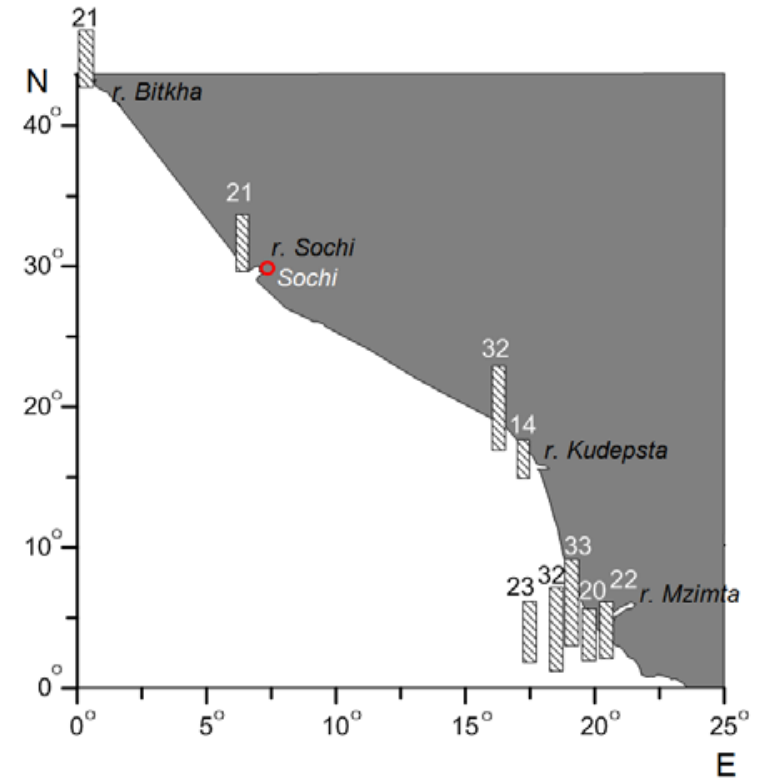

Fig. 4. Distribution of the AHC concentrations $(\mu \mathrm{g} / \mathrm{l})$ in the Big Sochi surface waters in May 2015
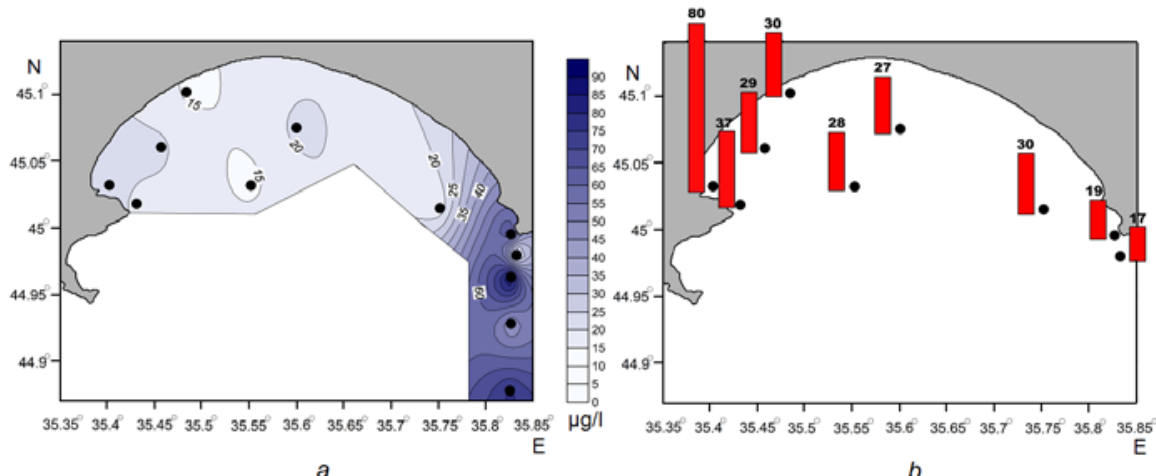

Fig. 5. The AHC content in the Feodosiya Bay in May 2015: $a$ - in the surface waters $(\mu \mathrm{g} / 1) ; b-$ in the bottom sediments $(\mu \mathrm{g} / \mathrm{l})$

In contrast to the surface waters in sandy sediments near Chauda Cape, the AHC content was only $17 \mu \mathrm{g} / \mathrm{g}$, which is comparable with the data of other researchers [11]. Low values of AHC are due to small sorption capacity of sand-shell sediments and rock outcrops, as well as to high dynamic activity of the water column [18]. Elevated concentrations of AHC are observed in the finely dispersed sediments of the Feodosiya port (up to $80 \mu \mathrm{g} / \mathrm{g}$, Fig. 5, b).

The PAHC content in the bottom sediments of the Feodosiya Bay varied within the range of 6-348 ng/g, while their higher concentrations were established both in the port area and in the area of Chauda Cape. The average content of unsubstituted polyarenes (in \%) decreased in the following sequence: CHR (23) > FL (21) > $>\mathrm{N}(16)>\mathrm{P}(14)>\mathrm{Ph}(11)>\mathrm{PL}$ (7) $>\mathrm{BP}$ (5) > AN (4) (Fig. 2, b). 
Despite the predominance of chrysene, having mainly biogenic origin, in the PAHC composition the increased concentrations of fluoranthene and pyrene may indicate the contamination of sediments by pyrogenic PAHC. This is also confirmed by the prevalence of pyrene over perylene (P/PL $=4-6.6)$, the exception is found in the sediments of the 1801station $(\mathrm{P} / \mathrm{PL}=0.7)$, located in the central part of the bay. The maximum concentration of naphthalene (28\%) at the station located near Chauda Cape can indicate sediment pollution by petroleum hydrocarbons in this area $[6,12]$.

During the complex monitoring of the Black Sea central part within the Russia economic zone in September 2015 (the 81st cruise of the R/V Professor Vodyanitsky) rather low concentrations of AHC were monitored: 9-21 $\mu \mathrm{g} / 1$ (Tab. 1, Fig. 6, a) in the surface waters, 23-34 $\mu \mathrm{g} / \mathrm{g}$ in the silty bottom sediments (Tab. 2, Fig. 6, $b$ ); i. e, they were at the level of the background ones [6]. The natural origin of AHC in the bottom sediments is indirectly indicated by the relations between the moisture content of the sediment, the concentrations of $\mathrm{C}_{\text {org }}$ and AHC, which values ranged from $r=0.75$ to $0.89(n=8)$, and also the low content of AHC in Corg composition (0.09\% on average) [6].
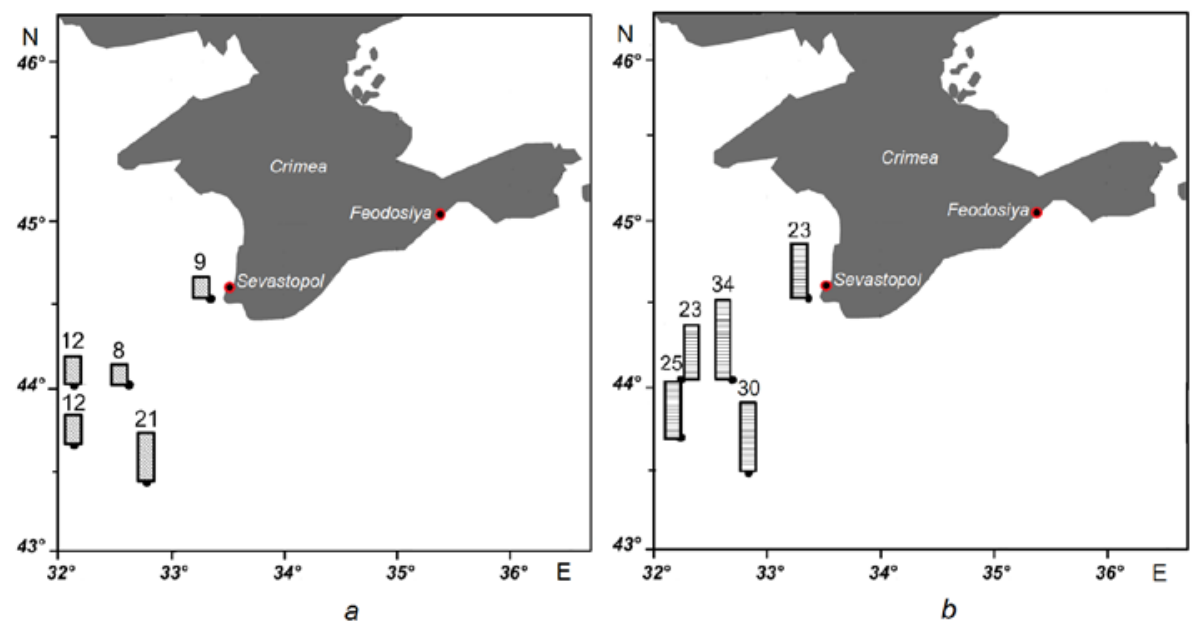

Fig. 6. The AHC content in the Black Sea central part in autumn 2015: $a$ - in the surface waters $(\mu \mathrm{g} / \mathrm{l}) ; b$ - in the bottom sediments $(\mu \mathrm{g} / \mathrm{l})$

Thus, in the studied areas, there was a large variability in the AHC concentrations in the suspended matter of surface waters. It was caused both by the hydrological features of the considered water areas and by the penetration of oil products, and also by the rapid utilization of organic compounds in the sea waters [19, 20]. The study of the inter-seasonal variability of the content of various pollutants in the Gelendzhik Bay surface waters showed that there is a sequential increase in the AHC concentrations from summer $(15 \mu \mathrm{g} / \mathrm{l})$ to winter $(30 \mu \mathrm{g} / \mathrm{l})$ reaching maximum in spring $(67 \mu \mathrm{g} / \mathrm{l})$ [20]. Under elevated summer temperatures, the transformation of OM, including AHC, increases, and with decreasing of the temperature, degradation processes slow down and accumulation of AHC takes place [6].

Due to the hydrophobic properties, the increase in the AHC concentrations is usually observed in areas with a higher content of suspended matter. To a lesser 
extent, the AHC distribution depends on the production characteristics of the area, in particular on chlorophyll $a$ [6]. Penetration of pollutants can disrupt these dependencies. Therefore, in the summer 2012 in the Gelendzhik Bay surface waters, the distribution of suspended matter and chlorophyll $a$ coincided $(r=0.86, n=12)$. At the same time, despite the low content of AHC, the dependence in the AHC and suspended matter distribution of is less pronounced: $r=0.40$. Due to the absence of large industrial facilities on the shore in the Gelendzhik Bay area, as well as remoteness from the main shipping routes, the AHC distribution is mainly affected by natural autochthonous processes. The low productivity of this area (chlorophyll a concentration is less than $1 \mu \mathrm{g} / \mathrm{l}$ ) also provides a low content of AHC in surface waters.

The water area adjacent to the Big Sochi was earlier considered one of the most polluted in the Black Sea Russian part [9,13 and 14]. As our data showed, the termination of the Olympic facilities construction and the current recreational policy led to a decrease in the amount of pollutants in the area. At the geochemical barrier of the river - sea, the AHC distribution was subordinated to the marginal filter regularities and there was a dependence in the AHC and suspended matter distribution in the Mzymta inflow area.

The reason for high concentrations of AHC in the Feodosiya Bay near Chauda Cape is the contaminated water penetration from the Kerch Strait [18, 21 and 22]. The main sources of pollution include ports, industrial enterprises located on the shore, sewage collectors, cargo terminals, single-buoy transshipment sites and waste landfills. According to the data of satellite sounding and direct measurements in the Feodosiya Bay, the penetration of water from the Sea of Azov occurs quite often. They are retained against the shore by the Black Sea Rim Current [18], which contributes to the AHC accumulation of in the area of Chauda Cape. It was established [22] that the contaminated water lenses produced by these sources are characterized by a high content of dissolved OM, oil products and suspended matter. According to the monitoring data in the Kerch Strait waters in 2013 and 2014, concentrations equal to or greater than TLV doubled (up to $49 \%$ ) with a maximum in August (210 $\mu \mathrm{g} / 1,4.2 \mathrm{TLV})$ [23].

In the bottom sediments, the distribution of the HC concentrations largely depends on their granulometric type. Particularly, the difference in the AHC accumulation by the bottom sediments with the change in their granulometric composition led to the fact that in the Danube estuary area in the surface layer of arenaceous deposits the average content of AHC was $20 \mu \mathrm{g} / \mathrm{g}$, in silty deposits - with an admixture of shells $-31 \mu \mathrm{g} / \mathrm{g}$, and actually in silts $-179 \mu \mathrm{g} / \mathrm{g}$ of dry sediment [6]. This confirms the realization of an increased sorption capacity of a finely dispersed material with respect to AHC. Therefore, in contrast to the surface waters, elevated concentrations of ACH in the bottom sediments are observed in the port of Feodosiya.

The obtained results on the AHC content in the bottom sediments of the studied areas are consistent with the previous data on coastal sediments of the Russian shelf $(15-170 \mu \mathrm{g} / \mathrm{g})[14]$ and deep-sea sediments of the Black Sea $(10-103 \mu \mathrm{g} / \mathrm{g})$. The AHC levels coincided with the concentrations established for the Mediterranean Sea sediments, but were significantly lower than in the water areas with constant oil entries $[6,14]$.

Despite the effect of oil and pyrogenic sources, the PAHC content in the studied sediments, according to the EPA classification [24], was rather low: up to $31 \mathrm{ng} / \mathrm{g}$ in PHYSICAL OCEANOGRAPHY ISS. 4 (2017) 
the Gelendzhik Bay and up to $348 \mathrm{ng} / \mathrm{g}$ in the Feodosiya Bay. These concentrations are considered background, or insignificant [12, 24], which coincided with the data of [13, 14], according to which the $\Sigma 17$ PAHC content in the Black Sea sediments was below $100 \mathrm{ng} / \mathrm{g}$. Earlier, the highest content was determined in the sediments in the Danube drift area (635 ng/g) and in the port water areas of Odessa (638 ng/g). In these samples, oil and pyrogenic polyarenes prevailed in composition of the PAHC sediments. However, these sediments are also considered to be moderately polluted, since under harmful concentrations of up to $2000 \mathrm{ng} / \mathrm{g}$, no adverse effects from the PAHC influence on humans are observed [24].

\section{Conclusions}

The highest concentrations of AHC are monitored in the coastal zones of the Black Sea Russian sector. The composition alkanes of suspended matter and bottom sediments were dominated by natural components. Petroleum and pyrogenic hydrocarbons are found mainly in the PAHC composition.

The HC accumulation occurred in the bottom sediments (especially coastal ones, where their concentrations exceeded the background ones in terms of the dry mass) and in the $\mathrm{C}_{\text {org }}$ composition of. Petroleum HCs increase the AHC level in water and sediments, and so that creating the present hydrocarbon background.

In the Big Sochi area there was a decrease in the AHC concentrations in the surface waters and in the bottom sediments in 2015 compared to 2013, the impact of the Olympic facilities construction was short-lived.

In the Feodosiya Bay area, the main source of the surface water pollution is the AHC penetration (up to $90 \mu \mathrm{g} / \mathrm{l}$ ) from the Kerch Strait. There are also increased concentrations of AHC and PAHC in the sediments $(80 \mu \mathrm{g} / \mathrm{g})$, since their content determines the granulometric composition of the deposits. A high proportion of naphthalene in the PAHC (9-28 \%) may indicate the presence of fresh oil products.

\section{Acknowledgements}

The authors are grateful to Zavyalov P. O., Kravchishina M. D., Kozina N. V. and Rezhepova Z. Yu. for their assistance in sampling; Demina L. V., Medvedeva A. V., Sychkova G. A. - for the assistance in carrying out the analysis.

The present work was supported by the Presidium of the Russian Academy of Sciences (Program No. 0149-2015-0056), as well as at the stage of summarizing the results and the publication preparation with the financial support of the Russian Science Foundation (Grants No. 14-27-00114P and 14-50-00095) and State Order No. 0149-2014-0038.

\section{REFERENCES}

1. Vorobyev, Yu.L., Akimov, V.A. and Sokolov, Yu.I., 2005. Preduprezhdenie i Likvidacija Avariynyh Razlivov Nefti i Nefteproduktov [Prevention and Liquidation of Oil Spills and Oil Products]. Moscow: In-Oktavo, 375 p. (in Russian).

2. $\quad$ Patin, S.A., 2008. Neftyanye Razlivy i ih Vozdeystvie na Morskuyu Sredu i Bioresursy [Oil Spills and their Impact on the Marine Environment and Living Resources]. Moscow: VNIRO, 508 p. (in Russian). 
3. Mityagina, M.I., Lavrova, O.Yu. and Bocharova, T.Yu., 2015. Sputnikovyy Monitoring Neftyanykh Zagryazneniy Morskoy Poverkhnosti [Satellite Monitoring of Oil Pollution of the Sea Surface]. Sovremennye Problemy Distantsionnogo Zondirovaniya Zemli iz Kosmosa, [e-journal] 12(5), pp.130-149. Available at: http://d33.infospace.ru/d33_conf/sb2015t5/130\%E2\%80\%93149.pdf [Accessed 14 December 2016] (in Russian).

4. Bondur, V.G. and Grebenyuk, Yu.V., 2001. Distantsionnaya Indikatsiya Antropogennykh Vozdeystviy na Morskuyu Sredu, Vyzvannykh Zaglublennymi Stokami: Modelirovanie, Eksperimenty [Remote Indication of Anthropogenic Influence on Marine Environment Caused by Depth Wastewater Plum: Modelling, Experiments]. Earth Observation and Remote Sensing, (6), pp. 49-67 (in Russian).

5. $\quad$ Oradovsky, S.G. ed., 1993. Rukovodstvo po Himicheskomu Analizu morskih Vod. RD 52.10. 243-92 [Guidelines for the Chemical Analysis of Marine Waters RD 52.10. 243-92]. St. Petersburg: Gidrometeoizdat, 265 p. Available at: http://docs.cntd.ru/document/1200042955 [Accessed 16 January 2017] (in Russian).

6. Nemirovskaya, I.A., 2013. Neft v Okeane (Zagrjaznenie i Prirodnye Potoki) [Oil in the Ocean (Pollution and Natural Flow)]. Moscow: Nauchnyj mir, 432 p. (in Russian).

7. Korshenko, A. ed., 2011. Kachestvo Morskikh Vod po Gidrokhimicheskim Pokazatelyam [Marine Water Pollution]. Annual Report 2010. Obninsk: Artifex, 196 p. Available at: http://www.oceanography.ru/images/stories/lmz/docs/ez/2010/ez_2010.pdf [Accessed 10 November 2016] (in Russian).

8. Vernadskiy, V.I., 2001. Himicheskoe Stroenie biosfery Zemli i eyo okruzheniya [The Chemical Structure of the Biosphere of the Earth and Its Environment]. Moscow: Nauka, 375 p. Available at: http://e-heritage.ru/ras/view/publication/general.html?id=46876289 [Accessed 21 August 2016] (in Russian).

9. USSR State Standart, 1990. GOST 17.1.4.02-90 Voda. Metodika Spektrofotometricheskogo Opredeleniya Khlorofilla a [Water. Spectrophotometric Determination of Chlorophyll a (GOST 17.1.4.02-90)]. Available at: http://docs.cntd.ru/document/1200009756 [Accessed 02 February 2017] (in Russian).

10. Nemirovskaya, I.A., Polyakova, A.V. and Yukhimuk, V.D., 2013. Raspredelenie i Sostav Uglevodorodov v Pribrezhnyh Vodah Severo-Vostochnoy Chasti Chernogo Morya [Distribution and Composition of Hydrocarbons in the Coastal Waters of the North-Eastern Part of the Black Sea]. Vestnik Moskovskogo Universiteta. Geografia=Moscow University Herald. Geography, (6), pp. 16-22 (in Russian).

11. Larin, A.A., Pavlenko, L.F., Skrypnik, G.V. and Korpakova, I.G., 2011. Zagryaznenie Pribrezhnoy Akvatorii Rossiyskogo Prichernomor'ya Neftyanymi Komponentami [Oil Pollution of the Black Sea Coastal Environment]. Marine Ecological Journal, (2), pp. 49-55 (in Russian).

12. Tolosa, I., De Mora, S., Sheikholeslami, M.R., Villeneuve, J.-P., Bartocci, J. and Cattini, C., 2004. Aliphatic and Aromatic Hydrocarbons in Coastal Caspian Sea Sediments. Mar. Pollut. Bull., [e-journal] 48(1-2), pp. 44-60. doi:10.1016/S0025-326X(03)00255-8

13. Wakeham, S.G., 1996. Aliphatic and Polycyclic Aromatic Hydrocarbons in Black Sea Sediments. Mar. Chem., [e-journal] 53(3-4), pp.187-205. doi:10.1016/0304-4203(96)00003-5

14. Readman, J.W., Fillmann, G., Tolosa, I., Bartocci, J., Villeneuve, J.-P., Cattini, C. and Mee, L.D., 2002. Petroleum and PAH Contamination of the Black Sea. Mar. Pollut. Bull., [e-journal] 44(1), pp. 48-62. doi:10.1016/S0025-326X(01)00189-8

15. AMAP, 2010. Assessment 2007: Oil and Gas Activities in the Arctic-Effects and Potential Effects. Oslo: AMAP. Vol. 2, pp. 4-1-4-86. Available at: https://www.amap.no/documents/doc/assessment-2007-oil-and-gas-activities-in-thearctic-effects-and-potential-effects.-volume-2/100 [Accessed 15 June 2016]. 
16. Lisitzin, A.P., 2004. Potoki Osadochnogo Veshchestva, Prirodnye Fil'try i Osadochnye Sistemy "Zhivogo Okeana" [Sediment Fluxes, Natural Filtration and Sedimentary Systems of a “Living Ocean”]. Russian Geology and Geophysics, [e-journal] 45(1), pp. 15-48. Available at: http://www.sibran.ru/journals/issue.php?ID=120378\&ARTICLE_ID=124514 [Accessed 08 December 2016] (in Russian).

17. Zavialov, P.O., Makkaveev, P.N., Konovalov, B.V., Osadchiev, A.A., Khlebopashev, P.V., Pelevin, V.V., Grabovskiy, A.B., Izhitskiy, A.S., Goncharenko, I.V., Soloviev, D.M. and Polukhin, A.A., 2014. Hydrophysical and Hydrochemical Characteristics of the Sea Areas adjacent to the Estuaries of Small Rivers of the Russian Coast of the Black Sea. Oceanology, [e-journal] 54(3), pp. 265-280. doi:10.1134/S0001437014030151

18. Kondratiev, S.I., 2009. Izmeneniya v Gidrohimicheskom Sostave Vod Feodosiyskogo Zaliva v Rezul'tate Proniknoveniya Azovomorskih Vod Zimoy 2006-2007 [Changes in the Hydrochemical Composition of Water of the Feodosiya Bay as a Result of Penetration of Waters of the Azov Sea in Winter 2006-2007]. In: MHI, 2009. Ekologicheskaya Bezopasnost' Pribrezhnoy i Shel'fovoy Zon i Kompleksnye Issledovaniya Resursov Shel'fa [Ecological Safety of Coastal and Shelf Zones and Comprehensive Use of Shelf Resources]. Sevastopol: ECOSIGidrofizika. Issue 18, pp. 30-37 (in Russian).

19. Lomakin, P.D., Chepyzhenko, A.I. and Chepyzhenko, A.A., 2016. Fields of the Dissolved Organic Matter Concentration in the Sea of Azov and the Kerch Strait Waters Based on Optical Observations. Physical Oceanography, [e-journal] (5), pp. 71-83. doi:10.22449/1573160X-2016-5-71-83

20. Agatova, A.I., 2014. Biokhimicheskiye Podkhody k Otsenke Produktivnosti Vod Mirovogo Okeana [Biochemical Approaches of Assessing the Productivity of the Waters of the World Ocean]. In: VNIRO, 2014. Trudy VNIRO [VNIRO Proceedings]. Vol. 152, pp. 15-40 (in Russian).

21. Chasovnikov, V.K., Chjoo, V.P., Ocherednik, O.A. and Mar’yasova, E.S., 2016. Evaluation of the Level of Technogenic Pollution in the Coastal Zone of the Black Sea near Gelendzhik. Oceanology, [e-journal] 56(1), pp. 70-74. doi:10.1134/S0001437016010021

22. Kushnir, V.M., Povazhny, V.V. and Berdnikov, S.V., 2014. Mineral'naya i Organicheskaya Komponenty Vzvesi po Dannym Kosmicheskih S"emok i Neposredstvennyh Izmereniy v Azovskom More i Kerchenskom Prolive [Mineral and Organic Components of the Suspension According to the Data of Space Surveys and Direct Measurements in the Azov Sea and the Kerch Strait]. Morskoy Gidrofizicheskiy Zhurnal, (2), pp. 22-31 (in Russian).

23. Korshenko, A. ed., 2014. Kachestvo Morskikh Vod po Gidrokhimicheskim Pokazatelyam [Marine Water Pollution]. Annual Report 2014. Moscow: Nauka, 156 p. Available at: http://oceanography.ru/images/stories/lmz/docs/ez/2014/ez_2014.pdf [Accessed 12 December 2016] (in Russian).

24. Savinov, V., Larsen, L.-H., Green, N., Korneev, O., Rybalko, A., Kochetkov, A. and Naumov, A., 2011. Monitoring of Hazardous Substances in the White Sea and Pechora Sea: Harmonisation with OSPAR's Coordinated Environmental Monitoring Programme (CEMP). Tromsø: Akvaplanniva, 71 p. Available at: http://www.miljodirektoratet.no/old/klif/publikasjoner/2757/ta2757.pdf [Accessed 07 May 2017]. 